UDC 663.813+658.562.64

DOI: $10.21668 /$ health.risk/2018.4.15.eng

Read

\title{
EXPERIENCE OF BUSINESS COMMUNITY ON HOW TO DETECT AND STOP MARKET DISTRIBUTION OF JUICES NOT CONFORMING TO LEGAL REQUIREMENTS
}

\author{
N.N. Ivanova, L.M. Khomich \\ "Russian Union of Juice Producers" (RSPS), a non-commercial organization, build 1, 3 Arkhangelsky Pereulok, \\ Moscow, 1101000, Russian Federation
}

Since 2010 The Russian Union of Juice Producers (RUJP) have been examining quality of juices that are sold on the Russian market. The basic goal here is to prevent manufacture and distribution of products that don't conform to legal requirements; to build up and maintain trust of consumers into juice products manufactured in the country; to create better conditions for fair competition. Since then, a control system has been built; is covers most juice manufacturers that work on the Russian market, procedures for research and results processing have been worked out and tested, and there is tight interaction between manufacturers, retailers and wholesalers, and state authorities responsible for control (surveillance). Quality monitoring system (QMS) is a structure created by the Russian Union of Juice Producers for accomplishing quality monitoring. QMS of the RUJP is similar to European systems for control over juices quality, such as EQCS (European Quality Control System for Juice and Nectars for Fruit and Vegetables), and SGF (Sure-Global-Fair). Annually the RUJP experts plan examinations (tests) of juices and decide on types of products that should be examined, a number of samples to be examined, and sampling criteria. Products to be examined are usually bought in retail outlets and they can be either manufactured by companies that are RUJP members or by side organizations. Products are purchased taking into account risk criteria worked out by the RUJP. There is an Expert Council that operates within the RUJP; its basic functions are to draw up examinations (tests) programs as per quality and safety criteria, assessment of marking and organoleptic properties of a product, as well as results of physical and chemical research. If any examination reveal a product that doesn't conform to legal requirements, the RUJP take action to stop its manufacturing and distribution on the market.

Key words: quality, juice, juice products, monitoring, risk criteria, quality control, system, examinations.

\section{Introduction.}

At present population in the RF consumes fruits and vegetables in quantities that are 25-30\% lower than recommended ${ }^{1}$ [1]. Juice products help to partially make up for the existing shortage of fruits and vegetables in people's nutrition. Up-to-date production technologies ensure correspondence of juices to natural structure of fruits and vegetables these juices are made of [2-5]; all the beneficial properties of fruits and vegetables are preserved in juices to the maximum possible extent [6]. And here some research reveals that certain nutrients are more biologically avail- able when they are consumed out of juices than out of fruits these juices are made of $[7,8]$. Overall, we can find more than 30 necessary nutrients and biologically active substances in juices [9-14].

Annually about 2.3 billion liters of juices products are consumed in Russia; they are juices, nectars, fruit drinks, and juice-containing drinks [15]. Most such products are manufactured by Russian enterprises; as per expert judgments, $97 \%$ share on the market belongs to Russian products. As juice manufacturing is highly developed in Russia, it becomes truly vital to provide good quality of

(C) Ivanova N.N., Khomich L.M., 2018

Natalya N. Ivanova - President (e-mail: rsps@rsps.ru; tel.: +7 (495) 628-99-19); ORCID: http://orcid.org/0000-00024604-7221).

Liudmila M. Khomich - Project Manager (e-mail: 1.homich@rsps.ru; tel.: +7 (495) 628-99-19; ORCID: http:// orcid.org/0000-0002-4312-3559).

${ }^{1}$ On Approval of recommendations on rational standards for food products consumption that correspond to the contemporary standards of healthy nutrition: The Order by the RF Public Healthcare Ministry No. 614 dated August 19, 2016 [Websource] // Kontur.Normative. - URL: https://normativ.kontur.ru/document?moduleId=1\&documentId=279426 (date of visit September 18, 2018). 
juice products, to make sure consumers have confidence in juice products, and to create favorable conditions for fair competition between manufacturers.

\section{European quality control systems for juice products.}

European self-regulating organizations have been performing control over juice products quality for several decades. There are both national and regional quality control systems for juice products. Some of them belong to EQCS (European Quality Control System for Juice and Nectars from Fruits and Vegetables that was established in 1994) ${ }^{2}$, some operate within SGF association (Sure-Global-Fair, established in 1986) ${ }^{3}$ either under EQCS control or beyond it. Nowadays about 30 European countries participate in this or that control system. All quality control systems are devoted to their common motto that goes as "Safety, Quality, and Fair Competition".

Self-control performed by participating manufacturers is a basic principle of all European quality control systems. It usually implements the most up-to-date techniques for laboratory research [16-19]. Manufacturers that participate in quality control systems operations widely apply voluntary audit on their enterprises. It helps to prevent distribution of poor quality products on the market. Additional quality control is accomplished via purchasing products in retail outlets and assessing their conformity with standards; such tests include also products manufactured by enterprises that are not covered by quality control systems. In case any products don't conform to fixed standards, their manufacturers are dealt with. In most cases issues are solved without any help from state controlling authorities.
Creation of a quality control system for juice products in Russia.

In 2002 several Russian manufactures who produced food products and were members of The Russian Union of Juice Producers (RUJP) signed "The 12th March 2002 Agreement". It was an attempt to create a nongovernmental self-regulating quality control system for juice products in Russia [16]. Juice products distributed on the Russian market were examined within this project but there was no further development and the project was terminated in 2007.

In 2010 the RUJP decided to return to such practices and initiated creation of a quality control system for juice products distributed on the RF territory. By that moment, all the necessary preconditions had occurred in Russia for creation of the Quality Monitoring System (QMS) that was aimed at detecting and eliminating distribution of products not conforming to legal requirements on the Russian market. The juice-producing branch was highly developed, there was a sufficient legal base, and competition on the marker was also great.

Overall development of the branch

On one hand, the branch is highly developed, both technically and technologically; on the other hand, products made by Russian manufacturers prevail on the market. It is also important that there is a solid basis for the system, namely the RUJP, an efficiently operating branch union that comprises manufacturers with $90 \%$ share of the overall juice products market.

Existing legal and regulatory base.

In 2008 the Federal Law No. 178-FL "The Technical Regulations for juice products made of fruits and vegetables" ${ }^{4}$ was issued;

\footnotetext{
${ }^{2}$ European Quality Control System for Juice and Nectars from Fruits and Vegetables [web-source]. - URL: http://www.eqcs.org/about-us/ (date of visit September 18, 2018).

${ }^{3}$ Sure-Global-Fair [web-source]. - URL: https://www.sgf.org/index.php?id=29\&L=1 (date of visit September 18, 2018).

${ }^{4}$ The Technical Regulations for juice products made of fruits and vegetables: The Federal Law issued on October от 27, 2008 No.178-FL [Web-source] //Garant. - URL: http://base.garant.ru/12163096/ (date of visit September 20, 2018).
} 
sufficient number of standards for research techniques has been developed. Therefore, there are certain "rules of the game" that are common for all the manufacturers. There are laboratories equipped with all the necessary devices and qualified experts who can perform measurements in the country. Besides there are experts with experience in the juice producing industry and particularly in inspecting juice products quality.

\section{Great competition on the market}

After 1998 economic crisis a lot of foreign companies left the Russian market thus stimulating domestic manufacturing. As per estimates given by package manufacturers, in 2000 approximately 100 companies produced juices in Russia. Juice market in the country was developing quite drastically in 2000s. Juice products outputs grew and in 2010 more than 3 billion liters of juice products were manufactured annually. The branch comprises both large manufacturers that specialize in juice products and a great number of smaller companies; new participants constantly appear on the market. As per the RUJP estimates, there are about 200 Russian enterprises that manufacture juice products.

The following tasks were to be solved within the Quality Monitoring System:

- to prevent manufacturing and market distribution of juice products that don't conform to legal requirements;

- to maintain public confidence in juice products;

- to create favorable conditions for fair competition. (QMS).

The RUJP Quality Monitoring System

The RUJP experts have created a control system that comprises most manufactures operating on the Russian market. They have developed and tested schemes for research performance and results processing; the organization interacts with manufacturers, state control (surveillance) authorities, and trade companies.

The System Council is a ruling body of the QMS and it is responsible for determining basic lines of the QMS activities and for making decisions as per research results. The Experts Council also operates within the QMS. Experts determine parameters for products research (examinations), assess marking and consumer package of products and inspect its organoleptic and physical-chemical properties in terms of their conformity with the requirements fixed in the Customs Union Technical Regulations. Qualified specialists who work in the juice manufacturing industry are among these experts.

The RUJP experts have worked out risk assessment criteria in order to efficiently determine products not conforming to legal requirements on the Russian market. They have outlined 17 risk criteria that can be conventionally divided into two groups, "manufacturer-related risks" and "product-related risks". "Manufacturer-related risks" are established on the basis of data on a manufacturer (a region, production volumes, types of package used in production, etc.) and (or) on the basis of research results obtained for products made by a manufacturer within the QMS. "Productrelated risks" are based on research data obtained for variable juice products (certain juice products that cause the highest risks, for example pomegranate juice) and (or) research results obtained for a specific product within the QMS. Each criterion is scored as per a scale (it can be from 1 to 5 scores or from 1 to 10 scores depending on a criterion). The criteria and their values are revised once a year taking into account new data obtained within monitoring activities.

\section{Activities related to quality monitoring within the QMS.}

Monitoring activities include the following basic stages: market research - examinations - results analysis - taking actions.

Marker research.

Since 2010 the RUJP have been keeping a register of juice products manufacturers that operate on the Russian market. This register contains data on manufacturers and their products. At present there are data on about 200 manufacturers and 2,700 various 
juice products in it. This register is used as a basis when products are selected for examinations.

\section{Examinations}

Examination programs are created by experts according to requirements fixed for juice products in the Customs Union Technical Regulations ${ }^{5}$. There are several types of such programs: basic, additional, and control ones. Basic programs are about examining samples of a specific juice product, for example, apple or orange juice. Additional programs can include examinations of products that are risky in terms of non-compliance, variable products as per a specific parameter, products in specific package, etc. Control programs are designed for products that previously were determined as non-compliant as per results of basic or additional examination programs. Control examinations are performed once a year with their basic purpose being to check whether corrections declared by manufacturers have been truly efficient and non-compliance has been eliminated.

Products samples for examinations are purchased in retail outlets all around the country, and products manufactured by enterprises that are the RUJP members and by those that are not are purchased equally. Purchased samples are given to certified test laboratories where they are examined as per physical and chemical parameters fixed by experts in the field. The RUJP cooperates with more than 10 laboratories (both domestic and foreign ones), and each sample is examined on average as per $20-25$ parameters.

Results analysis.

Results obtained via chemical and physical examinations are then submitted to the
QMS Experts Council. Experts also assess products marking and their organoleptic properties. A report on products compliance with the legal requirements is made on the basis of complex analysis. According to these requirements, juice products are to be made of fresh fruits and vegetables or fruits and vegetables that are preserved fresh via physical effort on their edible parts and should preserve all the properties of fruit or a vegetable they are made of ${ }^{5}$. And here each juice should preserve its unique nutrient profile [9-13]. Experts who perform examinations are to have profound knowledge on natural composure of fruits, vegetables, and juices made of them, as well as great experience in juice products identification.

\section{Taking actions.}

Results obtained in performed examinations and inspections results on products are sent to their manufacturers; the same results obtained for products manufactured as per orders from retail networks are sent to these networks. When non-compliance is detected, results are also sent to state control (surveillance) authorities in order to attract their attention to non-compliant products distributed on the market. The RUJP experts provide consultations in all cases when certain correcting actions are required for eliminating detected noncompliances [20, 21].

The results of QMS operations over 2010-2017.

Over 2010-2017 33 examination programs were accomplished within the QMS operations, 23 basic and 10 additional and control ones. Experts examined about 1,200 products samples manufactured by more than 150 manufacturers. Overall, assessment of research re-

${ }^{5}$ CU TR 021/2011. On food products safety: The Customs Union Technical Regulations [Web-source] // KODEKS: an electronic fund of legal and reference documentation. - URL: http://docs.cntd.ru/document/902320560 (date of visit September 20, 2018).

CU TR 022/2011. Food products as regards their marking: The Customs Union Technical Regulations [Websource] // KODEKS: an electronic fund of legal and reference documentation. - URL: http://docs.cntd.ru/document/902320347 (date of visit September 20, 2018).

CU TR 023/2011. TR for juice products made of fruits and vegetables: The Customs Union Technical Regulations [Web-source] // KODEKS: an electronic fund of legal and reference documentation. - URL: http:// docs.cntd.ru/document/902320562 (date of visit September 20, 2018). 
sults on juice products market reveals that about $95 \%$ juice products on the Russian market conform to legal requirements. Analysis of data obtained via control examinations shows that in $60 \%$ cases non-compliant products that have been detected due to monitoring are either brought to conformity or their production stops.

Results of the QMS activities have proven its efficiency as an instrument of non-governmental control aimed at improvement of juice products quality on the market; they also indicate it is necessary to further develop the RUJP activities in the sphere.

Funding. The research was not granted any sponsor support.

Conflict of interests. The authors state there is no any conflict of interests.

\section{References}

1. Potreblenie produktov pitaniya $\mathrm{v}$ domashnikh khozyaistvakh [Household food consumption]. Federal'naya sluzhba gosudarstvennoi statistiki: ofitsial'nyi sait. Available at: http://www.gks.ru/wps/ wcm/connect/rosstat_main/rosstat/ru/statistics/publications/catalog/doc_1140095125312

$(18.10 .2018)$ (in Russian).

2. Landon S. Fruit juice nutrition and health. Food Australia, 2007, vol. 59, pp. 533-538.

3. Nicklas T.A., O’Neil C., Fulgoni V. Replacing $100 \%$ Fruit Juice with Whole Fruit Results in a Trade Off of Nutrients in the Diets of Children. Current Nutrition and Food Science, 2015, vol. 11, no. 4, pp. 267-273.

4. Nicklas T.A., O’Neil C., Fulgoni V. Consumption of $100 \%$ Fruit Juice is Associated with Better Nutrient Intake and Diet Quality but not with Weight Status in Children: NHANES 2007-2010. Int. J. Child. Health Nutri., 2015, vol. 4, pp. 112-121.

5. Nicklas T.A., O'Neil C.E., Kleinman R. Association between $100 \%$ juice consumption and nutrient intake and weight of children aged 2 to 11 years. Arch. Pediatr. Adolesc. Med., 2008, vol. 162, pp. 557-565.

6. Clemens R., Drewnowski A., Ferruzzi M., Toner C.D., Welland D. Squeezing Fact from Fiction about 100 \% Fruit Juice: Workshop Proceedings. Adv. Nutri., 2015, vol. 6, no. 6-2, pp. 236s-241s.

7. Aschoff J.K., Rolke C.L., Breusing N., Bosy-Westphal A., Högel J., Carle R., Schweiggert R.M. Bioavailability of $\beta$-cryptoxanthin is greater from pasteurized orange juice than from fresh oranges - a randomized cross-over study. Mol. Nutr. Food Res., 2015, vol. 59, pp. 1896-1904.

8. Aschoff J.K., Riedl K.M., Cooperstone J.L., Hogel J., Bosy-Westphal A., Schwartz S.J., Carle R., Schweiggert R.M. Urinary excretion of Citrus flavanones and their major catabolites after consumption of fresh oranges and pasteurized orange juice - a randomized cross-over study. Mol. Nutr. Food Res., 2016, vol. 60, pp. 2602-2610.

9. Ivanova N.N., Khomich L.M., Perova I.B. Nutrientnyi profil' yablochnogo soka [Apple Juice Nutrient Profile]. Voprosy pitaniya, 2017, vol. 86, no. 4, pp. 125-136 (in Russian).

10. Ivanova N.N., Khomich L.M., Perova I.B. Orange juice nutritional profile. Voprosy pitaniya, 2017, vol. 86, no. 6, pp. 103-113 (in Russian).

11. Ivanova N.N., Khomich L.M., Beketova N.A. Tomato juice nutritional profile. Voprosy pitaniya, 2018, vol. 87, no. 2, pp. 53-64 (in Russian).

12. Ivanova N.N., Khomich L.M., Perova I.B., Eller K.I. Sour cherry juice nutritional profile. Voprosy pitaniya, 2018, vol. 87, no. 4, pp. 78-86 (in Russian).

13. Ivanova N.N., Khomich L.M., Perova I.B., Eller K.I. Nutrientnyi profil' greipfrutovogo soka [Grapefruit Juice Nutrient Profile]. Voprosy pitaniya, 2018, vol. 87, no. 5, pp. 85-94 (in Russian).

14. Souci S.W., Fachmann W., Kraut H. Food composition and nutrition tables, based on the 7th edition. Stuttgart, Medpharm GmbH Scientific Publishers, 2008, pp. 1198-1199.

15. RSPS podvodit itogi raboty za 2017 god / Novosti [RSEF summarizes the work for 2017 / News]. Rossiiskii soyuz proizvoditelei sokov (RSPS). Available at: http://www.rsps.ru/news (18.09.2018) (in Russian) (18.09.2018). 
16. Cozzolino D. Recent trends on the use of infrared spectroscopy to trace and authenticate natural and agricultural food products. Applied Spectroscopy Reviews, 2012, vol. 47, no. 7, pp. 518-530.

17. Benjamin S.R., de Oliveira Neto J.R., de Macedo I.Y.L., Bara M.T.F., Gunha L.C., de Faria Carvalho L.A., de Souza Gil E. Electroanalysis for Quality Control of Acerola (Malpighia emarginata) Fruits and their Commercial Products. Food Analytical Methods, 2015, vol. 8, no. 1, pp. 86-92.

18. Hosu A., Cimpoiu C. Thin-layer chromatography applied in quality assessment of beverages derived from fruits. Journal of Liquid Chromatography and Related Technologies, 2017, vol. 40, no. 5-6, pp. 239-246.

19. Nakonieczna A., Paszkowski B., Wilczek A., Szypłowska A., Skierucha W. Electrical impedance measurements for detecting artificial chemical additives in liquid food products. Food Control, 2016, vol. 66, pp. 116-129.

20. Vinogradova I.V. Metodicheskie rekomendatsii po samoregulirovaniyu kachestva produktsii. In-t nats. proekta "Obshchestv, dogovor" [Guidelines for self-regulation of product quality. Inst Nat project "Societies contract"]. Moscow, MakTsentr Publ., 2003, 73 p. (in Russian).

21. Chudakova E.A., Kashirina N.A. Vysokoe kachestvo i bezopasnost' sokovoi produktsii kak rezul'tat primeneniya strukturirovannoi sistemy menedzhmenta na predpriyatiyakh pishchevoi promyshlennosti [High quality and safety of juice products as a result of the use of a structured management system at food industry enterprises]. Tekhnologii i tovarovedenie sel'skokhozyaistvennoi produktsii, 2014, no. 3, pp. 66-75 (in Russian).

Ivanova N.N., Khomich L.M. Experience of business community on how to detect and stop market distribution of juices not conforming to legal requirements. Health Risk Analysis, 2018, no. 4, pp. 127-132. DOI: 10.21668/health.risk/2018.4.15.eng

Received: 16.10 .2018

Accepted: 14.12 .2018

Published: 30.12.2018 